\title{
Betaine- $\gamma$-aminobutyric Acid Transporter 1 (BGT-1/mGAT2) Interacts with the PDZ Domain of Munc-18 Interacting Proteins (Mints)
}

\author{
Sang-Jin Kim, Young Joo Jeong ${ }^{2}$, Sun Hee Choi ${ }^{2}$, Chun Yeon Choi ${ }^{2}$, Hee Jae Jun ${ }^{3}$, II Soo Moon ${ }^{4}$, \\ Dae-Hyun Seog ${ }^{2}$ and Won Hee Jang $^{2}$ * \\ ${ }^{1}$ Departments of Neurology, ${ }^{2}$ Departments of Biochemistry, ${ }^{3}$ Departments of Thoracic and Cardiovascular Surgery, College of Medicine, Inje \\ University, Busan 614735, Korea \\ ${ }^{4}$ Departments of Anatomy, College of Medicine, Dongguk University, Gyeongiu 780-714, Korea
}

Received August 23, 2012 /Revised September 6, 2012 /Accepted September 7, 2012

\begin{abstract}
The action of neuronally released $\gamma$-aminobutyric acid (GABA) is terminated by uptake into the neurons by GABA transporters (GATs). The mechanism underlying the stabilization and regulation of GAT2 has not yet been elucidated. We used the yeast two-hybrid system to identify proteins that interact with and, thereby, regulate betaine- $\gamma$-aminobutyric acid transporter 1 (BGT-1/mGAT2). We found an interaction between BGT-1/mGAT2 and Munc-18-interacting proteins (Mints). The "T-H-L" motif at the C-terminal end of BGT-1/mGAT2 was essential for the interaction with Mint2 in the yeast two-hybrid assay. Mint2 bound to the tail region of BGT-1/mGAT2, but not to other GAT members. When co-expressed in HEK-293T cells, Mint2 was co-immunoprecipitated with BGT-1/mGAT2. In addition, we demonstrated the cellular co-localization of BGT-1/mGAT2 and Mint2 in the cells. These results suggest that Mint2 contributes to the regulation of BGT-1/mGAT2.
\end{abstract}

Key words : Neurotransmitter transporter, $\gamma$-aminobutyric acid transporter, betaine- $\gamma$-aminobutyric acid transporter 1 (BGT-1), Munc-18-interacting protein 2 (Mint2), PDZ Domain

\section{Introduction}

Plasma membrane neurotransmitter transporters exist for most of the small molecule neurotransmitter systems [2]. $\gamma$-aminobutyric acid (GABA) is the primary inhibitory neurotransmitter in the brain and has been implicated in numerous neurogical disorders, including epilepsy, anxiety, and bipolar disorder $[10,23,25]$. GABA transporters (GATs) belong to the family of $\mathrm{Na}^{+} / \mathrm{Cl}^{-}$dependent transporters that also includes transporters for the neurotransmitters such as dopamine, serotonin, norepinephrine and glycine $[12,19]$. GATs are found primarily in the presynaptic membrane. This localization suggests that GATs are involved in regulating synaptic transmission and transmitter recycling [6,21].

Recently, four different subtypes of GATs have been cloned with diverse regional, cellular and subcellular location [19]. These have been termed mGAT1, mGAT2, mGAT3 and mGAT4 when referring to transporters cloned from mice. Betaine- $\gamma$-aminobutyric acid transporter (BGT-1) was

*Corresponding author

Tel : +82-51-890-6974, Fax : +82-51-894-5801

E-mail : daehyun@inje.ac.kr and whjang@inje.ac.kr originally cloned from the Madin-Darby canine kidney (MDCK) cell line $[6,12,17,19]$. Subsequently, the homologous transporter mGAT2 was cloned from mouse brain [12,19]. BGT-1/mGAT2 is a membrane transporter capable of utilizing both GABA and betaine as substrates $[10,13,29]$. Betaine is known as an organic osmolyte involved in osmoregulation in the kidneys [6]. BGT-1/mGAT2 contains 614 amino acids and shares $54 \%$ identity with GAT1 $[7,19]$. Previous studies have reported that GAT1 activity can be modulated by protein-protein interactions. The interaction between the N-terminal cytoplasmic tail of GAT1 and syntaxin 1A causes a 4-fold decrease in substrate transporter rates [8]. The interaction between the C-terminus of GAT1 and Pals1 containing the PDZ domain contributes to the stability of GAT1, thus promoting the expression level of the transporter protein [8].

The topologies of BGT-1/mGAT2 consist of 12 hydrophobic transmembrane domains and the amino and carboxyl termini face the cytoplasm [2,17]. The cytosolic C-terminus contains postsynaptic density-95 (PSD-95)/ discs large protein/zona occludens 1 (PDZ)-association motif which is recognized by the adaptor protein-binding sites found in membrane-associated proteins [14,27]. PDZ-association motifs are 
characterized by a C-terminal hydrophobic residue and a free carboxylate group at the -2 position (T/S-X-V/D/L) $[9,11]$. PDZ interactions have been found to be involved in the multi-molecular organization of receptors and signal transduction pathways [14]. BGT-1/mGAT2 contains a typical PDZ-association motif (T-X-L) in its cytosolic C-terminal domain [5].

In order to investigate the BGT-1/mGAT2-mediated regulation of GABAergic neurotransmission, we screened for proteins that interact with the C-terminus of BGT-1/mGAT2 through the yeast two-hybrid system and identified Mint2 (also called X11-like protein), a PDZ domain-containing protein [20]. The BGT-1/mGAT2 and Mint2 interaction suggests that Mint 2 contributes to the regulation of BGT- $1 /$ mGAT2 in the synaptic membrane.

\section{Materials and Methods}

\section{Plasmid constructs}

Full-length rat Mint2 in the pRC/CMV vector (a gift from M. Setou, Hamamatsu University, Hamamatsu, Japan) was tagged with a myc-epitope and fused with EGFP at the amino-terminus. Truncations of BGT-1/mGAT2 [17] were utilized as a template to amplify the region coding for amino acids 570-628 using the appropriate primers. The amplified fragment was subcloned into T-vector. The fragment was then EcoRl-restricted and subcloned into the EcoRI site of pLexA. The correct orientation and in-frame cloning of cDNA inserts was verified by restriction enzyme analysis, and DNA sequencing. FLAG-tagged BGT-1/mGAT2 construct was used in all experiments that utilized mammalian cell expression system. General recombinant DNA techniques were performed according to standard protocol [24].

\section{Screening of BGT-1/mGAT2-binding proteins by yeast two-hybrid assay}

The Matchmaker LexA two-hybrid system was used for screening according to the manufacturer's manual (Clontech, Palo Alto, CA, USA). In brief, a part of the BGT-1/mGAT2 gene was fused to the DNA-BD region of the pLexA vector using the PCR and the plasmid DNA was transformed into yeast strain EGY48 carrying the p8op-lacZ gene. Transformed EGY48 yeast cells containing the BGT-1/ mGAT2 bait plasmid were transformed with the mouse brain cDNA library [15] and grown on synthetic dextrose (SD) plates supplemented with glucose but with no histi- dine, tryptophan, or uracil (SD/-His/-Trp/-Ura). The selection of positive clones was performed on an $\mathrm{SD} /$-His/-Trp/-Ura/-Leu plate containing galactose, raffinose, X-gal, and BU salts. Plasmids from positive clones were analyzed by restriction digestion. Unique inserts were sequenced and protein sequence analysis was performed with the BLAST algorithm at the National Center for Biotechnology Information (NCBI). Sequence-verified clones were tested again for interactions with the bait in yeast by the retransformation.

\section{Cell culture and Transfection}

HEK-293T cells were cultured in Dulbecco's modified Eagle's medium supplemented with $10 \%$ fetal bovine serum, L-glutamine, and antibiotics. Transient transfections were done with the $\mathrm{CaPO}_{4}$ precipitation method.

\section{Immunocytochemistry}

Cells grown on poly-D-lysine-coated coverslips were transfected with myc-EGFP-Mint2 and FLAG-BGT-1/ mGAT2 constructs. Twenty-four hours after transfection, cells were washed with phosphate-buffered saline (PBS), fixed with $4 \%$ paraformaldehyde in PBS for $5 \mathrm{~min}$, and permeabilized with $0.2 \%$ Triton X-100 in PBS for $10 \mathrm{~min}$. After blocking with $5 \%$ normal goat serum in PBS for $30 \mathrm{~min}$, cells were incubated with anti-BGT-1 antibody (Alpha Diagnostic International, San Antonio, TX, USA) diluted 1:500 in PBS containing $1 \%$ bovine serum albumin (BSA) and $0.05 \%$ Tween-20 overnight at $4^{\circ} \mathrm{C}$. After washing with PBS 3 times, cells were incubated with Dylight 594-conjugated goat anti-rabbit IgG antibody (Jackson ImmunoResearch Labs, West Grove, PA, USA) diluted 1:800 for $40 \mathrm{~min}$. For nuclear staining, cells were incubated with $1 \mu \mathrm{g} / \mathrm{ml} \mathrm{4,} \mathrm{6-dia-}$ midino-2-phenylindole (DAPI) (Sigma-Aldrich) in PBS for 5 min. After washing with PBS 3 times, the cells were mounted with Fluoromount (DAKO). Fluorescence images were acquired on Zeiss LSM510 META confocal laser scanning microscope (Carl Zeiss, Oberkochem, Germany).

\section{Co-immunoprecipitation}

Twenty-four hours after transfection, cells were rinsed with ice-cold PBS twice and lysed with ice-cold lysis buffer [PBS containing $0.5 \% \mathrm{NP}-40$ and $1 \mathrm{x}$ protease inhibitor cocktail set $\mathrm{V}$ (Calbiochem)] by gentle rotation for $30 \mathrm{~min}$. Lysates were centrifuged at $16,000 \times \mathrm{g}$ for $10 \mathrm{~min}$ at $4^{\circ} \mathrm{C}$. The supernatant (soluble fraction) was incubated with anti-FLAG 
M2 agarose beads (Sigma-Aldrich) for $2 \mathrm{hr}$ at $4^{\circ} \mathrm{C}$ with constant shaking. The beads were collected by centrifugation at 2,000x $g$ for $30 \mathrm{sec}$ and washed 5 times with ice-cold lysis buffer. The immunoprecipitated proteins were analyzed by Western blotting.

\section{Results}

Identification of BGT-1/mGAT2 interacting proteins by yeast two-hybrid screening

To identify BGT-1/mGAT2-interacting proteins, we screened a mouse brain cDNA library through the yeast two-hybrid assays using the C-terminal region of BGT-1/mGAT2 as bait (Fig. 1C). From $6 \times 10^{6}$ colonies screened, we obtained 6 positive clones. Three clones (clone 1, 3 and 5) of the 6 clones were identical and possessed a C-terminal fragment of Mint2 containing the PDZ domain (Fig. 1A). Mint2 is composed of several protein-protein interaction domains, two PDZ domains and one PTB domain (Fig. 1A). To determine the binding domain of Mint2 that is required for the interaction with BGT-1/mGAT2, we con- structed a series of deletion mutants of Mint2. Yeast two-hybrid assays with BGT-1/mGAT2 showed that the minimal domain required for binding was critically dependent on the second PDZ domain of Mint2 (Fig. 1B). Next we investigated whether the last seven amino acids of BGT-1/mGAT2 contain a functional PDZ-association motif that mediates protein-protein interaction. For this purpose, a series of C-terminal deletion mutants of BGT-1/mGAT2 were constructed (Fig. 1C), and co-transfected into yeast cells with pLexA-Mint2. As shown in Fig. 1C, the C-terminal deletion mutants of BGT-1/mGAT2 did not interact with Mint2. These result indicated that the interaction between BGT-1/mGAT2 and Mint2 is mediated through a PDZ-mediated interaction similar to the previously described a class I PDZ interaction $[9,27]$.

When the C-terminal cytoplasmic regions of mGAT1, BGT-1/mGAT2, mGAT3 and mGAT4 were tested for Mint2-binding, there was no detectable binding between Mint2 and the tail domains of mGAT1, mGAT3 and mGAT4 (Fig. 2A). These data indicate that the interaction of Mint2 with GATs is specific to the cytoplasmic region of

A

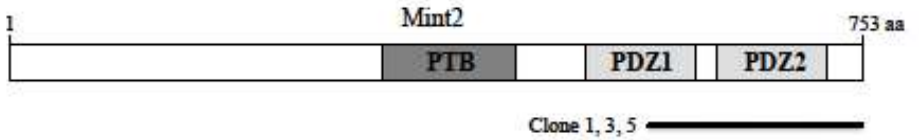

B

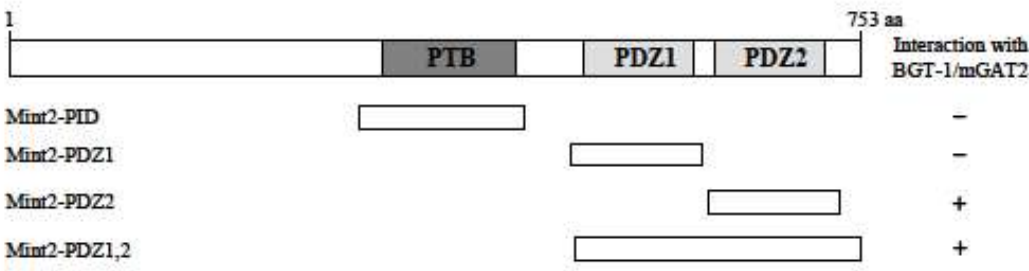

C

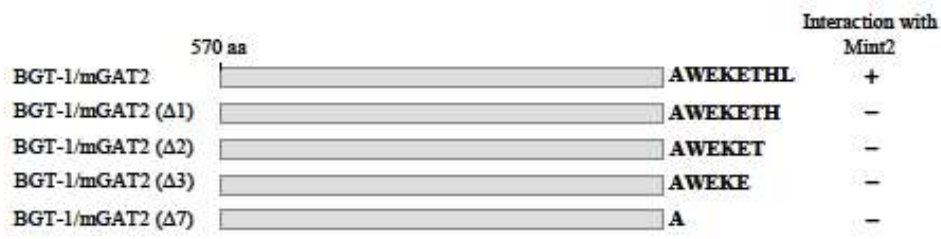

Fig. 1. Identification of the proteins interacting with BGT-1/mGAT2 by yeast two-hybrid screening. (A) The domain structure of Mint2 illustrating that clones 1, 3, and 5 possess a fragment of Mint2 containing the PDZ domain. PTB and PDZ domains are indicated in gray. aa, the amino acid residue number. (B) Minimal BGT-1/mGAT2 binding region in Mint2. Different truncations of Mint2 were constructed by PCR. Several truncated forms of Mint2 were tested in the yeast two-hybrid assay for interaction with BGT-1/mGAT2. +, interaction with BGT-1/mGAT2; -, no interaction with BGT-1/mGAT2. aa, the amino acid residue number. (C) Specific interaction of Mint2 with the C-terminus of BGT-1/mGAT2. Several deletion mutant forms of BGT-1/mGAT2 were tested in the yeast two-hybrid assay for interaction with Mint2. +, interaction with Mint2; -, no interaction with Mint2. 


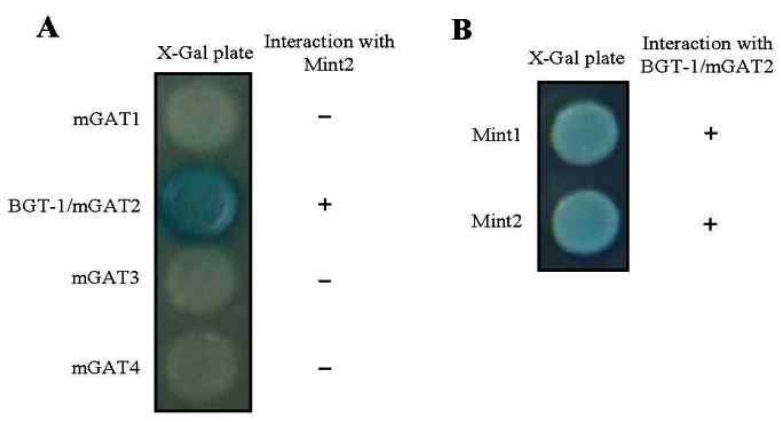

Fig. 2. Interaction between GATs and Mint proteins. The C-terminal region of each GAT protein and full length Mints were fused to the pLexA DNA binding domain. (A) Mint2 specifically interacted with BGT-1/mGAT2 but not with mGAT1, mGAT3 or mGAT4 $(+$, interaction with Mint2; -, no interaction with Mint2). (B) BGT-1/mGAT2 interacted with Mint1 and Mint2 (+, interaction with BGT-1/mGAT2; - , no interaction with BGT-1/mGAT2).

BGT-1/mGAT2 isoform. Interaction was also detected between BGT-1/mGAT2 and other Mint family member, Mint1 (Fig. 2B).

\section{BGT-1/mGAT2 is associated with Mint2 in cells}

To assess the interaction of BGT-1/mGAT2 and Mint2 in mammalian cells, HEK-293T cells were co-transfected with constructs expressing myc-EGFP-Mint2 along with FLAG-BGT-1/mGAT2 (Fig. 3). Cell lysates were immunoprecipitated with a monoclonal antibody directed against the FLAG epitope followed by Western blot analysis with anti-BGT-1 antibody. Fig. 3 shows that BGT-1/mGAT2

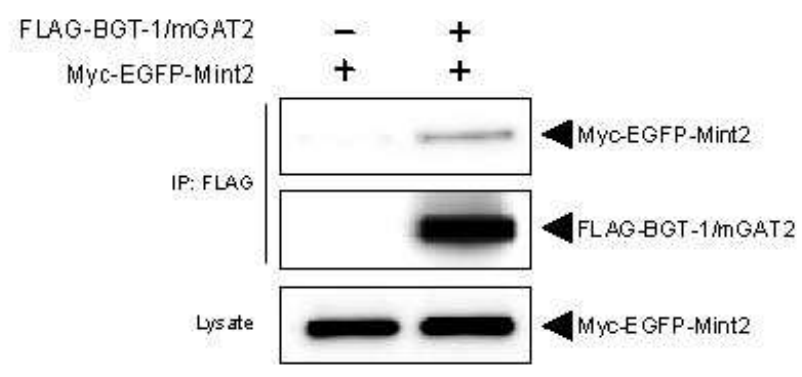

Fig. 3. BGT-1/mGAT2 and Mint2 were co-immunoprecipitated from mammalian cells. HEK-293Tcells were transiently transfected with Myc-EGFP-Mint2 plasmid and either control vector or FLAG-BGT-1/mGAT2 plasmid as indicated. Cell lysates were incubated with monoclonal anti-FLAG antibody to immunoprecipitate BGT-1/ mGAT2. Western blots were subsequently probed with anti-myc antibody and anti-FLAG antibodies. Mint2 was specifically co-immunoprecipitated with BGT-1/ mGAT2.

co-precipitated Mint2. As expected from our yeast two-hybrid results, BGT-1/mGAT2 specifically interacts with Mint2.

For a potential interaction between BGT-1/mGAT2 and Mint2 to be physiologically relevant, two proteins must co-localize at the same subcellular region in cells. To determine whether BGT-1/mGAT2 and Mint2 co-localize, we generated the N-terminal EGFP-fused Mint2 construct. BGT-1/mGAT2 was co-transfected with EGFP-Mint2 into HEK-293T cells. BGT-1/mGAT2 and Mint2 co-localized at the same subcellular region in cells (Fig. 4A). Co-transfected BGT-1/mGAT2 and Mint2 revealed a largely plasma mem-

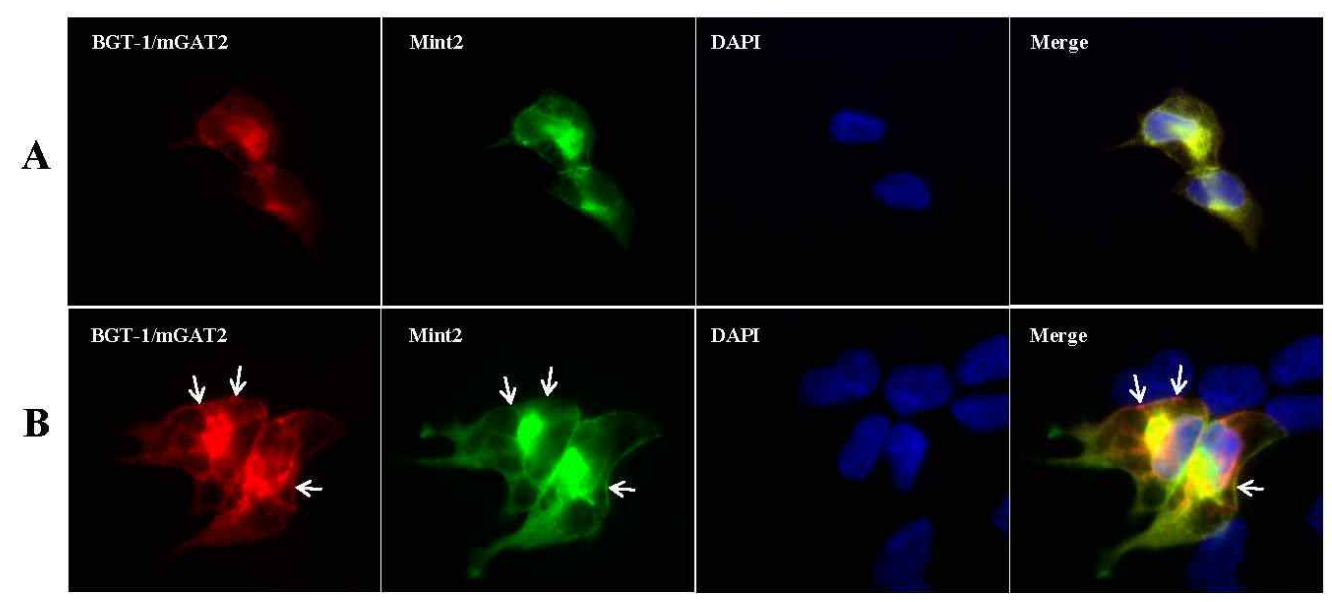

Fig. 4. Co-localization of BGT-1/mGAT2 and Mint2 at the plasma membrane. Twenty-four hours after transfection, cells were immunostained using anti-BGT-1antibody. (A) BGT-1/mGAT2 and EGFP-Mint2 are seen at the same subcellular region in cells. (B) Immunofluorescence staining of BGT-1/GAT2 and EGFP-Mint2 shows that both proteins co-localize largely in plasma membrane (arrow). 
brane expression in a subset cells, forming clusters at the cell surface (Fig. 4B). This result indicates that Mint2 is a specific binding partner of BGT-1/mGAT2 in cell level.

\section{Discussion}

In this study, we have shown that the neuronal plasma membrane BGT-1/mGAT2 can associate with Mint2. Using the intracellular carboxyl tail of BGT-1/mGAT2 as bait, we identified Mint2 in a yeast two-hybrid screen of a mouse brain cDNA library. The three C-terminal amino acids containing region of BGT-1/mGAT2 can interact with Mint2. Furthermore, when full-length BGT-1/mGAT2 and Mint2 are expressed in mammalian cells, they co-immunopresipitate and co-localize in cells. This is the first demonstration of an interaction at the C-terminus of BGT-1/mGAT2 and joins Mint2 as a BGT-1/mGAT2-interacting protein.

Interestingly, Mint2 has two PDZ domains that mediate interaction with the other protein [20]. This study demonstrated through domain analysis by yeast two-hybrid assay that the interaction is dependent upon the second PDZ domain of Mint2 and the C-terminal amino acids of BGT-1/mGAT2. The C-terminal three amino acids (T-H-L) represent a class I PDZ domain ligand [9]. PDZ-domain proteins play important roles in establishing and maintaining an asymmetry of membrane proteins in neurons [14]. Proteins containing PDZ domains usually possess multiple protein-protein interaction domains, allowing them to form multimeric complexes [11]. PDZ domains contain a conserved peptide-binding groove that associates with the extreme C-terminus of ligands [9]. Although we did not show whether BGT-1/mGAT2 can bind with other PDZ domain containing proteins, our results suggest that the interaction between BGT-1/mGAT2 and Mint2 is mediated through a PDZ interaction.

Mint2 is a multidomain protein composed of PTB and PDZ domains [20]. The N-terminal domain of Mint2 binds to cell-surface receptors [4] and Munc18-1, a protein essential for synaptic vesicle exocytosis [28]. The central phosphotyrosine binding (PTB) domain binds to the cytoplasmic tail of amyloid- $\beta$-protein precursor (APP) [3]. PDZ domains bind to presenilins [16], cell surface receptors, $\mathrm{Ca}^{2+}$ channels [18], and kinesin KIF17 [26]. Thus Mint2 resembles adaptor proteins that connect the N-terminal, PTB domain, and PDZ domain interactions. Protein-protein interactions not only determine the specific membrane surface expression, but can also affect the membrane surface expression level by altering endocytic rates. In cultured neuron, co-expression of PSD-95 and NMDA receptor NR2B results in decreased endocytosis of NR2B, while deletion of the PDZ-association motif yields an increase in the percentage of receptor that is internalized [22]. Interestingly, the C-terminal PDZ-association motif of BGT-1/mGAT2 is responsible for proper targeting and maintenance at basolateral membrane surface of MDCK cells $[1,5]$.

How might an interaction with Mint2 modulate BGT-1/mGAT2 surface expression? One potential model is the association with Mint2 to prevent internalization from surface membrane. Recent evidence for many different transporter systems suggests that direct interacting proteins of the transporter serves as a tag that identifies transporters to be internalized [22]. This might occur because the tag is indicative of a transporter in an appropriate conformational state for internalization. Thus, like PSD-95, it may be that the interaction between BGT-1/mGAT2 and Mint2 induces conformational state that confers a slowing of BGT-1/mGAT2 internalization from membrane surface. Further functional studies on this and other BGT-1/mGAT2 interacting proteins may help to shed light on the regulating BGT-1/mGAT2 activity.

\section{Acknowledgment}

This work was supported by an Inje University Research Grant for 2011.

\section{References}

1. Ahn, J., Mundigl, O., Muth, T. R., Rudnick, G. and Caplan, M. J. 1996. Polarized expression of GABA transporters in Madin-Darby canine kidney cells and cultured hippocampal neurons. J. Biol. Chem 271, 6917-6924.

2. Amara, S. G. and Kuhar, M. J. 1993. Neurotransmitter transporters: recent progress. Annu. Rev. Neurosci. 16, 73-93.

3. Biederer, T., Cao, X., Südhof, T. C. and Liu, X. 2002. Regulation of APP-dependent transcription complexes by Mint/X11s: differential functions of Mint isoforms. $J$. Neurosci. 22, 7340-7351.

4. Biederer, T., Sara, Y., Mozhayeva, M., Atasoy, D., Liu, X., Kavalali, E. T. and Südhof, T. C. 2002. SynCAM, a synaptic adhesion molecule that drives synapse assembly. Science 297, 1525-1531.

5. Brown, A., Muth, T. and Caplan, M. 2004. The COOH-terminal tail of the GAT-2 GABA transporter contains a novel 
motif that plays a role in basolateral targeting. Am J. Physiol. Cell Physiol. 286, C1071-C1077.

6. Burnham, C. E., Buerk, B., Schmidt, C. and Bucuvalas, J. C. 1996. A liver-specific isoform of the betaine/GABA transporter in the rat: cDNA sequence and organ distribution. Biochim Biophys. Acta. 1284, 4-8.

7. Clausen, R. P., Frølund, B., Larsson, O. M., Schousboe, A., Krogsgaard-Larsen, P. and White, H. S. 2006. A novel selective gamma-aminobutyric acid transport inhibitor demonstrates a functional role for GABA transporter subtype GAT2/BGT-1 in the CNS. Neurochem Int. 48, 637-642.

8. Deken, S. L., Beckman, M. L., Boos, L. and Quick, M. W. 2000. Transport rates of GABA transporters: regulation by the N-terminal domain and syntaxin 1A. Nat. Neurosci. 3, 998-1003.

9. Doyle, D. A., Lee, A., Lewis, J., Kim, E., Sheng, M. and MacKinnon, R. 1996. Crystal structures of a complexed and peptide-free membrane protein-binding domain: molecular basis of peptide recognition by PDZ. Cell 85, 1067-1076.

10. Gether, U., Andersen, P. H., Larsson, O. M. and Schousboe, A. 2006. Neurotransmitter transporters: molecular function of important drug targets. Trends Pharmacol. Sci. 27, 375-383.

11. Gomperts, S. N. 1996. Clustering membrane proteins: It's all coming together with the PSD-95/SAP90 protein family. Cell 84, 659-662. 2

12. Guastella, J., Nelson, N., Nelson, H., Czyzyk, L., Keynan, S., Miedel, M. C., Davidson, N., Lester, H. A. and Kanner, B. I. 1990. Cloning and expression of a rat brain GABA transporter. Science 249, 1303-1306.

13. Iversen, L. 2006. Neurotransmitter transporters and their impact on the development of psychopharmacology. Br. J. Pharmacol. 147, Suppl. 1, S82-S88.

14. Kennedy, M. B. 2000. Signal-processing machines at the postsynaptic density. Science 290, 750-754.

15. Kim, S. J., Lee, C. H., Park, H. Y., Yea, S. S., Jang, W. H., Lee, S. K., Park, Y. H., Cha, O. S., Moon, I. S. and Seog, D. H. 2007. JSAP1 interacts with kinesin light chain 1 through conserved binding segments. J. Life Sci. 17, 889-895.

16. Lau, K. F., McLoughlin, D. M., Standen, C. and Miller, C. C. 2000. X11 alpha and $x 11$ beta interact with presenilin-1 via their PDZ domains. Mol. Cell Neurosci.16, 557-565.

17. Liu, Q. R., Mandiyan, S., Nelson, H. and Nelson, N. 1992. A family of genes encoding neurotransmitter transporters. Proc. Natl. Acad Sci. USA 89, 6639-6643.
18. Maximov, A., Südhof, T. C. and Bezprozvanny, I. 1999. Association of neuronal calcium channels with modular adaptor proteins. J. Biol. Chem 274, 24453-24456.

19. Nelson, N. 1998. The family of $\mathrm{Na}+\mathrm{Cl}-$ neurotransmitter transporters. J. Neurochem 71, 1785-1803.

20. Okamoto, M. and Südhof, T. C. 1997. Mints, Munc-18 -interacting proteins in synaptic vesicle exocytosis. J. Biol. Chem 272, 31459-31464.

21. Radian, R., Ottersen, O. P., Storm-Mathisen, J., Castel, M. and Kanner, B. I. 1990. Immunocytochemical localization of the GABA transporter in rat brain. J. Neurosci. 10, 1319-1330.

22. Roche, K. W., Standley, S., McCallum, J., Dune Ly, C., Ehlers, M. D. and Wenthold, R. J. 2001. Molecular determinants of NMDA receptor internalization. Nat. Neurosci. 4, 794-802.

23. Roettger, V. R. and Amara, S. G. 1999. GABA and glutamate transporters: therapeutic and etiologic implications for epilepsy. Adv. Neurol.79, 551-560.

24. Sambrook, J., Fritsch, E. F. and Maniatis, T. 1989. Molecular cloning: a laboratory manual. Cold Spring Habor Laboratory, Cold Spring Habor, New York.

25. Schousboe, A., Larsson, O. M., Sarup, A. and White, H. S. 2004. Role of the betaine/GABA transporter (BGT-1/GAT2) for the control of epilepsy. Eur. J. Pharmacol. 500, 281-287.

26. Setou, M., Nakagawa, T., Seog, D. H. and Hirokawa, N. 2000. Kinesin superfamily motor protein KIF17 and mLin-10 in NMDA receptor-containing vesicle transport. Science 288, 1796-1802.

27. Sheng, M. and Sala, C. 2001. PDZ domains and the organization of supramolecular complexes. Annu. Rev. Neurosci. 24, 1-29.

28. Verhage, M., Maia, A. S., Plomp, J. J., Brussaard, A. B., Heeroma, J. H., Vermeer, H., Toonen, R. F., Hammer, R. E., van den Berg, T. K., Missler, M., Geuze, H. J. and Südhof, T. C. 2000. Synaptic assembly of the brain in the absence of neurotransmitter secretion. Science 287, 864-869.

29. White, H. S., Watson, W. P., Hansen, S. L., Slough, S., Perregaard, J., Sarup, A., Bolvig, T., Petersen, G., Larsson, O. M., Clausen, R. P., Frølund, B., Falch, E., KrogsgaardLarsen, P. and Schousboe, A. 2005. First demonstration of a functional role for central nervous system betaine/gamma-aminobutyric acid transporter (mGAT2) based on synergistic anticonvulsant action among inhibitors of mGAT1 and mGAT2. J. Pharmacol. Exp. Ther. 312, 866-874. 
초록 : Betaine- $\gamma$-aminobutyric acid transporter 1 (BGT-1/mGAT2)과 Munc-18-interacting (Mint) 단백질의 PDZ 결합

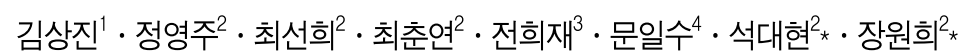

(인제대학교 의과대학 ${ }^{1}$ 신경과학교실, ${ }^{2}$ 생화학교실, ${ }^{3}$ 흥부외과학교실, ${ }^{4}$ 동국대학교 의과대학 해부학교실)

$\gamma$-Aminobutyric acid (GABA)는 신경세포 밖으로 분비된 후 GABA 수송체들(GATs)에 의하여 다시 신경세포 안으로 재흡수 된다. 그러나, GABA 수송체들이 어떻게 연접전막의 위치에 안정적으로 존재하는지 또한 어떤 단 백질과 결합하여 조절을 받는지는 알려져 있지 않다. 본 연구에서 효모 two-hybrid system을 이용하여 betaine- $\gamma$ -aminobutyric acid transporter 1 (BGT-1/mGAT2)의 C-말단과 특이적으로 결합하는 Munc-18-interacting (Mint) 단백질을 분리하였다. BGT-1/mGAT2의 C-말단에 존재하는 "T-H-L" 아미노산배열은 Mint2와의 결합에 필수적 으로 관여하였다. Mint2은 BGT- $1 / \mathrm{mGAT} 2$ 와는 결합하지만, 다른 종류의 GAT와는 결합하지 않았다. 또한 HEK-293T 세포에 Mint2와 BGT-1/mGAT2을 동시에 발현시켜 면역침강한 결과 두 단백질은 같이 면역침강하였 으며, 두 단백질은 세포 내에서 세포막 부위에 같이 존재함도 확인하였다. 이러한 결과들은 Mint2가 BGT- $1 / \mathrm{mGAT} 2$ 와 결합하여 BGT-1/mGAT2을 조절하는 역할을 함을 시사한다. 